\title{
PENALARAN MATEMATIK MELALUI PENDEKATAN OPEN-ENDED DALAM PEMBELAJARAN MATEMATIKA
}

\author{
Oleh: Almira Amir, M.Si ${ }^{1}$ \\ e-mail: almira_stain09@yahoo.com
}

\begin{abstract}
Mathematical reasoning is the foundation for obtaining or constructing mathematical knowledge so that teachers must be able to nurture students to develop mathematical reasoning and be able to deepen their ideas in the field of mathematics. The selection of appropriate learning approaches will support the development of these capabilities. Innovation and creativity of teachers to develop learning mathematics is expected so as to improve students' mathematical reasoning ability, able to compete in facing the challenges of the times as it is today. One alternative to overcome the problem is through the Open-Ended approach in mathematics learning. Learning with Open-Ended approach is a way to improve the learning of mathematics during this less varied, and through this approach is expected students can explore all the capabilities it has to be poured in solving every problem given.
\end{abstract}

ABSTRAK

Penalaran matematik adalah dasar untuk memperoleh atau membangun pengetahuan matematika sehingga guru harus dapat membina siswa untuk mengembangkan penalaran matematika dan dapat memperdalam ide-ide mereka di bidang matematika. Pemilihan pendekatan pembelajaran yang tepat akan mendukung pengembangan kemampuan ini. Diharapkan inovasi dan kreativitas guru untuk mengembangkan pembelajaran matematika sehingga dapat meningkatkan kemampuan penalaran matematis siswa, mampu bersaing dalam menghadapi tantangan zaman seperti sekarang ini. Salah satu alternatif untuk mengatasi masalah tersebut adalah melalui pendekatan Open-ended dalam pembelajaran matematika. Pembelajaran dengan pendekatan Open-ended merupakan cara untuk meningkatkan pembelajaran matematika selama ini yang kurang variatif, dan melalui pendekatan ini diharapkan siswa dapat menggali 
semua kemampuan yang harus dituangkannya dalam menyelesaikan setiap masalah yang diberikan.

Kata kunci: Penalaran Matematik, Pendekatan Open-ended, Pembelajaran Matematika

\section{PENDAHULUAN}

Pendidikan adalah suatu proses enkulturasi yang dialami individu selama hidupnya secara sadar atau pun tidak sadar untuk mencapai kompetensi yang bertujuan mengembangkan nilai-nilai dan norma kebudayaan serta prestasi masa lalu menjadi nilai-nilai budaya dan karakter bangsa yang sesuai dengan kehidupan masa kini dan masa mendatang. Pendidikan juga merupakan usaha sadar suatu masyarakat dan bangsa dalam mempersiapkan generasi untuk menghadapi tantangan demi keberlangsungan hidup di masa yang akan datang. Proses di atas merupakan proses penting dan berkelanjutan yang harus dilakukan dalam semua mata pelajaran khususnya pada pelajaran matematika.

Matematika merupakan mata pelajaran yang dipelajari di setiap jenjang pendidikan sehingga peserta didik memiliki kemampuan berpikir logis, kritis, sistematis, analitis, dan kreatif. Matematika juga memiliki peranan sangat penting dalam berbagai disiplin ilmu lain serta memiliki peranan untuk mengembangkan daya pikir manusia. Oleh karena itu, peserta didik harus menguasai matematika sehingga memudahkan dalam memahami bidang ilmu lainnya. Ruseffendi menyatakan bahwa matematika penting untuk dipelajari, baik sebagai alat bantu, sebagai ilmu, sebagai pembimbing pola pikir, maupun sebagai pembentuk sikap.1

Dalam menghadapi era informasi dan daya saing yang semakin ketat, maka diperlukan pengembangan kemampuan dalam bidang studi untuk dilaksanakan dalam pembelajaran setiap bidang studi demikian juga dalam pembelajaran matematika. Menurut Utari Sumarmo, bahwa pengembangan kemampuan matematika tersebut termuat dalam rumusan tujuan pembelajaran matematika (dalam KTSP 2006) yaitu: a) memahami konsep matematika, menjelaskan keterkaitan antar konsep dan mengaplikasikan konsep atau algoritma secara luwes, akurat, efisien, dan tepat dalam pemecahan masalah, b) menggunakan penalaran pada pola dan sifat, melakukan manipulasi matematika dalam membuat generalisasi, menyusun bukti, atau menjelaskan gagasan dan pernyataan matematika, c) memecahkan masalah; d) mengkomunikasikan gagasan dengan simbol, tabel, diagram, atau media lain untuk memperjelas keadaan atau masalah,

\footnotetext{
${ }^{1}$ Ruseffendi, E.T. Pengantar kepada Membantu Guru Mengembangkan Kompetensinya dalam Pengajaran matematika untuk Meningkatkan CBSA. (Bandung: Tarsito, 1991), hlm. 156
} 
dan e) memiliki sikap menghargai kegunaan matematika dalam kehidupan, sikap rasa ingin tahu, perhatian, dan minat dalam mempelajari matematika, serta sikap ulet dan percaya diri dalam pemecahan masalah.2

Tujuan dipelajarinya matematika di sekolah agar peserta didik dapat menggunakan penalaran pada pola dan sifat untuk melakukan manipulasi matematika dalam membuat generalisasi, menyusun bukti, atau menjelaskan gagasan dan pernyataan matematika. Menurut National Council of Teacher of Mathematics (NCTM, 2000), salah satu tujuan mempelajari matematika adalah belajar untuk bernalar (mathematical reasoning). Ball, Lewis \& Thamel (dalam Widjaya, 2010) menyatakan "mathematical reasoning is the foundation for the construction of mathematical knowledge". Hal ini menunjukkan bahwa penalaran matematika adalah fondasi untuk mendapatkan atau menkonstruksi pengetahuan matematika. Dengan demikian, guru harus mampu membina peserta didik untuk mengembangkan kemampuan penalarannya sehingga mampu mendalami ide-ide dan proses mengkostruksi pengetahuannya dalam bidang matematika.

Kemampuan penalaran matematik sangat penting bagi peserta didik karena berperan dalam: 1) melatih peserta didik dalam proses berpikir kritis dan logis (Shurter dan Pierce dalam Sumarmo; ${ }_{3}$ Suherman dan Winataputra; Hudojo, 1988) $)_{5}$; 2) menuntun peserta didik dalam menyusun dan menguji konjektur, menyusun pembuktian (Sumarmo) 6 ; 3) menuntun peserta didik untuk dapat menganalisis, mengevaluasi, menggeneralisasi, mensintesis/mengintegrasikan (Mullis, et. al.)7.

Inovasi dan kreativitas guru untuk mengembangkan pembelajaran matematika sangat diharapkan sehingga mampu meningkatkan kemampuan penalaran matematis siswa, mampu bersaing dalam menghadapi tantangan zaman

\footnotetext{
2Utari Sumarmo, Pembelajaran Matematika Berbasis Karakter (Prosiding Seminar Nasional Pendidikan Matematika STKIP Siliwangi Bandung Vol. 1, 2011)

${ }^{3}$ Sumarmo, U. "Kemampuan Pemahaman Dan Penalaran Matematik Siswa SMA Dikaitkan Dengan Kemampuan Penalaran Logik Siswa Dan Beberapa Unsur Proses Belajar Mengajar." Dissertation In Post Graduate Study, Institut Keguruan Dan Ilmu Pendidikan (Bandung. Un published, 1987).

${ }^{4}$ Suherman, E dan Winataputra, U.S. Strategi Belajar Mengajar Matematika, (Jakarta: Universitas Terbuka, 1993).

${ }^{5}$ Hudoyo, Pengembangan Kurikulum Matematika dan Pelaksanaannya di Depan Kelas. (Surabaya: Usaha Nasional, 1988).

${ }^{6}$ Sumarmo, U. Pembelajaran Matematika untuk Mendukung Pelaksanaan Kurikulum Berbasis Kompetensi. (Makalah Disajikan pada Pelatihan Guru, 2002).

${ }^{7}$ Mullis, et al., TIMSS Assessment Frameworks and specifications 2003. 2nd Edition. (International Study Center, Lynch School of Education, Boston College, 2003).
} 
seperti sekarang ini. Salah satu alternatif untuk mengatasi permasalahan tersebut adalah melalui pendekatan Open-Ended dalam pembelajaran matematika.

Hal ini sesuai dengan pendapat Suherman, et. al yang dikutip dalam Herdiman, bahwa problem yang diformulasikan agar memiliki multijawaban yang benar disebut problem tak lengkap atau disebut juga problem open-ended atau problem terbuka ${ }^{8}$. Penerapan problem open-ended dalam kegiatan pembelajaran adalah ketika siswa diminta mengembangkan metode, cara, atau pendekatan yang berbeda dalam menjawab permasalahan yang diberikan dan bukan berorientasi pada jawaban atau hasil akhir. Tujuan utama siswa dihadapkan dengan problem open-ended adalah bukan untuk mendapatkan jawaban tetapi lebih menekankan pada bagai-mana cara siswa/mahasiswa sampai pada suatu jawaban. Jadi, tidak hanya ada satu pendekatan atau metode dalam memperoleh jawaban, namun beberapa atau banyak. Menurut Jerry P. Becker \& Shigeru Shimada dalam Herdiman, bahwa pendekatan open-ended memberikan beberapa hal yang dapat dijadikan acuan dalam mengkreasi masalah tersebut, antara lain (1) menyajikan permasalahan melalui situasi fisik yang nyata dimana konsep matematika dapat dikaji dan diamati siswa; (2) soal-soal pembuktian dapat diubah sedemikian rupa sehingga siswa dapat menemu-kan hubungan dan sifat-sifat dari variabel dalam masalah itu; (3) menyajikan bangun-bangun geometri sehingga siswa dapat membuat suatu konjektur; (4) memberikan suatu barisan bilang-an atau tabel bilangan sehingga siswa dapat menemukan aturan matematika; serta (5) memberikan contoh konkret dalam beberapa kategori sehingga siswa dapat mengelaborasi sifat-sifat dari contoh itu untuk menemukan sifat-sifat yang umum ${ }^{9}$.

Dari hasil penelitian para peneliti terdahulu yaitu bahwa pembelajaran matematika dengan menggunakan pendekatan Open-Ended sangat membantu peserta didik diantaranya mampu meningkatkan kemampuan berpikir kritis dan kreatif siswa ${ }^{10}$, efektif dalam aspek penalaran dan pemecahan masalah ${ }^{11}$, mampu

\footnotetext{
${ }^{8}$ Herdiman, I. Penerapan pendekatan open-ended untuk meningkatkan pemahaman dan penalaran matematik serta kemandirian belajar siswa SMP (Tesis STKIP Siliwangi, tidak diterbitkan, 2015), hlm. 18

${ }^{9}$ lbid., hlm. 20

${ }^{10}$ Yandri Soeyono. Pengembangan Bahan Ajar Matematika dengan Pendekatan OpenEnded untuk Meningkatkan Kemampuan Berpikir Kritis dan Kreatif Siswa SMA, (PYTHAGORAS: Jurnal Pendidikan Matematika Volume 9-Nomor 2, Desember 2014), hlm. 205-218.

${ }^{11}$ Joko Sulianto, Keefektifan Model Pembelajaran Kontekstual dengan pendekatan open ended dalam aspek penalaran dan pemecahan masalah pada materi segitiga di kelas VII. (Malih Peddas: Majalah Ilmiah Penddikan Dasar Vol 1, No 1, 2011), hlm. 205-218.
} 
meningkatkan kemampuan koneksi matematika ${ }^{12}$. Hal ini menunjukkan bahwa pendekatan Open-Ended sangat membantu dalam pembelajaran matematika khususnya terhadap kemampuan penalaran matematik peserta didik. Karakteristik dari pembelajaran dengan pendekatan open-ended adalah memberikan masalah terbuka pada awal pembelajaran (terutama yang bersifat kontekstual) yang mempunyai beberapa jawaban. Selanjutnya, dengan melakukan refleksi dan analisa terhadap beberapa jawaban/solusi yang ditemukan, siswa diajak untuk berpikir secara kritis untuk menentukan jawaban mana yang merupakan jawaban terbaik menurut pemikirannya dengan berbagai alasan yang logis.

Dari beberapa hasil penelitian diatas, bahwa pembelajaran dengan pendekatan open-ended merupakan suatu cara untuk 'mereformasi' pembelajaran matematika selama ini yang kurang variatif, dan melalui pendekatan ini diharapkan siswa dapat mengeksplorasi segala kemampuan yang dimilikinya untuk dituangkan dalam menyelesaikan setiap permasalahan yang diberikan.

Dalam tulisan ini, penulis mendeskripsikan tentang kemampuan penalaran matematik melalui pendekatan Open-Ended dalam pembelajaran matematika.

\section{PEMBAHASAN}

\section{Pembelajaran Matematika}

Pembelajaran matematika merupakan suatu kegiatan yang kompleks, melibatkan berbagai unsur seperti guru, siswa, matematika dan karakteristiknya, dan situasi belajar yang berlangsung. Oleh karena itulah pembelajaran tidak dapat disederhanakan menjadi suatu resep untuk membantu siswa belajar. Paling sedikit terdapat dua hal yang menjadi alasan bahwa pembelajaran tidak dapat dirumuskan dalam bentuk resep. Pertama, pembelajaran melibatkan pengetahuan tentang: topik matematika yang akan diajarkan, perbedaan siswa, cara siswa belajar, lingkungan kelas, lembaga pendidikan dan masyarakat. Selain hal umum seperti di atas, guru juga harus mempertimbangkan hal-hal khusus misalnya: karakteristik topik yang akan diajarkan dan pedagogi mengajarkannya. Kedua, sebagai implikasi bahwa pembelajaran melibatkan berbagai domain, maka guru juga harus menetapkan: cara mengajukan dan merespons pertanyaan, cara menyajikan idea matematika secara tepat, berapa lama diskusi perlu dilaksanakan,

\footnotetext{
${ }^{12}$ Eka Kasah Gordah, Upaya Guru Meningkatkan Kemampuan Koneksi dan Pemecahan Masalah Matematis Peserta Didik melalui Pendekatan Open Ended, (Jurnal Pendidikan dan Kebudayaan Vol 18, No 3, 2012)
} 
jenis dan kedalaman tugas matematika, dan keseimbangan antara tujuan dan pertimbangan.

NCTM dalam Utari Sumarmo mengemukakan beberapa saran kepada guru dalam melaksanakan pembelajaran matematika secara bermakna yaitu dengan memilih tugas matematik yang tepat, mendorong berlangsungnya belajar bermakna, mengatur diskursus (discourse), dan berpartisipasi aktif dalam pembelajaran matematika sehingga tercipta suasana belajar yang kondusif.

a. Memilih tugas hendaknya memperhatikan: topik-topik matematika yang relevan, pemahaman, minat, dan pengalaman belajar siswa yang sebelumnya, dan mendorong tercapainya belajar bermakna,

b. Memilih tugas ditujukan untuk mengembangkan pemahaman dan keterampilan matematik, menstimulasi tersusunnya hubungan matematik, mendorong untuk formulasi masalah, pemecahan masalah dan penalaran matematik, memajukan komunikasi matematik, menggambarkan matematika sebagai kegiatan manusia, mendorong tumbuhnya disposisi matematik.

c. Mengatur diskursus dengan cara : memperkenalkan notasi dan bahasa matematika yang tepat, menyajikan informasi, menjelaskan isu, membuat model, dan memberi kesempatan siswa mengatasi kesulitan serta meyakinkan diri siswa; mendorong partisipasi siswa untuk menciptakan suasana kelas yang kondusif; mendengarkan, merespon, dan bertanya melalui berbagai cara untuk bernalar, membuat koneksi, menyelesaikan masalah, dan saling berkomunikasi; mengajukan pertanyaan/masalah, contoh dan lawan contoh, konjektur.

d. Menciptakan suasana belajar untuk mendorong pengembangan daya matematik siswa dengan cara: mengajukan pertanyaan dan menyusun konjektur, idea dan masalah kontekstual yang sesuai; menghargai idea, cara berfikir dan disposisi matematik siswa melalui belajar individual atau kolaboratif

e. Menganalisis partisipasi belajar siswa melalui: observasi terhadap apa yang telah dipelajari siswa.13

Dengan terciptanya suasana pembelajaran matematika yang kondusif dan siswa melakukan pembelajaran bermakna, maka pemahaman siswa terhadap pelajaran matematika dapat meningkat. Pembelajaran bermakna adalah proses belajar dengan mengaitkan informasi atau pengetahuan-pengetahuan yang telah dimiliki dengan informasi yang baru. Menurut Ausubel kebermaknaan pembelajaran akan membuat kegiatan belajar lebih menarik, lebih bermanfaat, dan lebih menantang sehingga konsep dan prosedur matematika akan lebih mudah

13 Utari Sumarmo, loc. cit., 
dipahami dan mudah diingat oleh peserta didik ${ }_{14}$. Jika seseorang ingin mempelajari sesuatu tanpa mengaitkan hal satu dengan yang lain yang sudah diketahui, maka proses maupun hasil pembelajarannya adalah sebagai hafalan dan tidak bermakna sama sekali baginya.

Di sinilah peran guru sangat dibutuhkan untuk memberikan kemudahan bagi para siswanya sehingga mereka dapat mengaitkan pengalaman dan pengetahuan barunya dengan pengetahuan yang dimiliki. Untuk dapat melaksanakan perannya tersebut, guru harus mengetahui potensi yang dimiliki siswa terlebih dahulu kemudian menggunakan strategi untuk meningkatkannya. Salah satunya yaitu mengetahui dan meningkatkan penalaran siswa. Dengan mengetahui penalaran siswa, guru diharapkan dapat merencanakan serta melaksanakan pembelajaran matematika yang tepat sehingga terlaksana pembelajaran yang optimal.

Terlaksananya pembelajaran matematika yang tepat, maka tidak terlepas dari tujuan dari pembelajaran itu sendiri seperti yang dinyatakan oleh Permendiknas No. 22 tahun 2006 adalah (1) menggunakan penalaran pada pola dan sifat, melakukan manipulasi matematika dalam membuat generaliasi, menyusun bukti, atau menyusun gagasan dan pernyataan matematika dan (2) memecahkan masalah yang meliputi kemampuan memahami masalah, merancang model matematika, menyelesaikan model dan menafsirkan solusi yang diperoleh. Dari tujuan tersebut dapat diketahui bahwa dengan pembelajaran matematika, siswa diharapkan mampu menggunakan penalaran dan memecahkan masalah seperti yang terdapat pada kegiatan pembelajaran dengan menggunakan pendekatan scientific dalam kurikulum 2013. Oleh karena itu, aspek penalaran dan pemecahan masalah harus diperhatikan oleh guru.

\section{Kemampuan Penalaran Matematik}

Istilah nalar atau penalaran merupakan terjemahan dari kata reasoning yang artinya jalan pikiran seseorang. Penalaran adalah suatu cara berpikir yang menghubungkan antara dua hal atau lebih berdasarkan sifat dan aturan tertentu yang telah diakui kebenarannya menggunakan langkah-langkah pembuktian hingga mencapai suatu proses mental dalam menarik kesimpulan (generalization) dengan alasan-alasan yang syah $_{15}$.

\footnotetext{
${ }^{14}$ Gatot Muhsetyo, Pembelajaran Matematika SD (Tangerang Selatan: Universitas Terbuka, 2015), hlm. 1.9

${ }^{15}$ Hasratuddin, Mengapa Harus Belajar Matematika? (Medan: Perdana Publishing, 2015), hlm. 91
} 
Menurut Ball, Lewis dan Thames dalam Widjaya, "mathematical reasoning is foundation for the construction of mathematical knowledge". Fondasi dari matematika adalah penalaran (reasoning). Penalaran bagian terpenting dari matematika penalaran merupakan proses berpikir yang dilakukan untuk menarik kesimpulan berdasarkan fakta dan sumber yang relevan ${ }_{16}$. Oleh karena itu, dalam berbagai aktivitas pembelajaran matematika, peserta didik harus dikondisikan agar selalu menggunakan penalaran yang bersifat logis, kritis, sistematis, tepat, jelas, cermat dan akurat. Selanjutnya diharapkan kemampuan bernalar tersebut harus menjadi pola pikir, pola sikap, dan pola tindak peserta didik, baik dalam kegiatan yang berkaitan dengan matematika maupun dalam aktivitas sehari-hari.

Selanjutnya, De Lange menyatakan bahwa kompetensi atau kemampuan termuat dalam matematika adalah berpikir dan bernalar secara matematis (mathematical thinking and reasoning), berkomunikasi secara matematis (mathematichal communication), beargumentasi secara matematis (mathematichal argumentation), pemodelan (modelling), penyusunan dan pemecahan masalah (problem posing and solving), representasi (representation), simbol (symbol), dan sarana teknologi (tools and technology) 17.

Menurut Principles and Standards for School Mathematics dalam NCTM standar penalaran matematis meliputi 18 :

a. Recognize reasoning and proof as fundamental aspect of mathematics (Mengenal penalaran sebagai aspek mendasar dari matematika),

b. Make and investigate mathematical conjecture (Membuat dan menyelidiki dugaan matematis)

c. Develop and valuate mathematical arguments and proof (Mengembangkan dan mengevaluasi argumen matematika)

d. Select and use various types of reasoning and methods of proof (Memilih dan mengggunakan berbagai tipe penalaran).

Sehubungan dengan itu, dorongan dan kesempatan yang didapat mahasiswa di kelas untuk melakukan penalaran dalam rangka memecahkan masalah matematik merupakan fondasi yang diperlukan untuk mencapai standar penalaran yang dirumuskan NCTM tersebut.

\footnotetext{
${ }^{16}$ Widjaya, W. Design Realistic Mathematics Education Lesson. Makalah Seminar Nasional Pendidikan, (Program Pascasarjana Universitas Sriwijaya, Palembang, 2010), hlm. 5.

${ }^{17}$ De Lange, J. Mathematical literacy for living from OECD-PISA perspective. (Tsukuba Journal of Educational Study in Mathematics, 2006), hlm. 24

${ }^{18}$ NCTM. Principles and Standards for School Mathematics. (Drive, Reston, VA: The NCTM, 2000), hlm. 402.
} 
Penalaran matematika ditandai dengan beberapa indikator sebagai berikut ${ }_{19}$ :

a. Mampu mengajukan dugaan (conjecture)

b. Memberikan alasan atau bukti terhadap kebenaran suatu pernyataan

c. Menarik kesimpulan dari suatu pernyataan

d. Memeriksa keshahihan argumen

e. Menentukan pola pada suatu gejala matematis

f. Memberikan alternatif bagi suatu argumen

Menurut Ahmad Nizar, bahwa berdasarkan indikator penalaran matematika tersebut, maka karakteristik soal matematika yang tergabung dalam penalaran matematika adalah sebagai berikut 20 :

a. Soal yang mengharuskan peserta didik untuk mampu mengajukan argumen. Karakteristik utama soal ini adalah meminta siswa menduga yang kemudian dibuktikan dengan menampilkan beragam konsep yang dikuasai peserta didik yang ada hubungannya dengan permasalahan yang diberikan.

b. Soal yang mengharuskan peserta didik memberikan alasan atau bukti terhadap suatu pernyataan. Karakteristik soal ini setidaknya dapat menggugah siswa untuk menyelesaikan permasalahan dengan model yang dikembangkan siswa sendiri.

c. Soal yang mengharuskan peserta didik menarik kesimpulan dari suatu pernyataan. Karakteristik soal ini adalah menekankan kejelian atau ketelitian peserta didik dalam menentukan kebenaran dari suatu pernyataan.

d. Soal yang memungkinkan peserta didik untuk memeriksa keshahihan argumen. Karakteristik soal ini biasanya dimulai dengan menyebutkan jawaban suatu masalah atau pernyataan yang sengaja dibuat salah. Tujuannya hanyalah memancing ketelitian peserta didik menyelidiki benar tidaknya argumen.

e. Soal yang memungkinkan peserta didik untuk menentukan pola pada suatu gejala matematis. Karakteristik dari soal ini biasanya meminta siswa meneliti pola secara tidak langsung akan membuat kesimpulan dari pola yang ditemukannya.

f. Soal yang memungkinkan peserta didik untuk memberikan alternatif bagi suatu argumen. Karakteristik dari soal ini memungkinkan peserta didik untuk melakukan dengan berbagai cara sesuai aturan untuk menyelesaikan suatu soal dan membantunya mengingat kembali konsep yang telah dimengertinya.

\footnotetext{
${ }^{19}$ Hasratuddin, Op. Cit., hlm. 95

${ }^{20}$ Achmad Nizar. Kontribusi Matematika dalam Membangun Daya Nalar dan Komunikasi Siswa, (Jurnal Pendidikan Inovatif/Vol. 2, No.2, 2007), hlm 75-78
} 
Dari indikator penalaran di atas, menunjukkan bahwa untuk melihat kemampuan penalaran seseorang, konteks instrumennya mengarah pada pembuktian dan jastifikasi. Secara umum penalaran digolongkan pada dua jenis, yaitu penalaran induktif dan penalaran deduktif.

Penalaran induktif merupakan suatu kegiatan untuk menarik kesimpulan atau membuat suatu pernyataan baru yang bersifat umum berdasar pada beberapa pernyataan khusus yang diketahui benar. Selama proses pembelajaran di kelas, penalaran induktif dapat digunakan ketika siswa mempelajari konsep atau teorema baru. Penalaran ini banyak digunakan oleh siswa sekolah dasar ketika mereka mempelajari berbagai pola yang ada dalam matematika. Penalaran induktif dimulai dengan memeriksa keadaan khusus menuju penarikan kesimpulan umum, yang dinamakan proses induktif generalisasi. Penalaran tersebut mencakup pengamatan contoh-contoh khusus dan menemukan pola atau aturan yang melandasinya.

\section{Pendekatan Open-Ended}

Pendekatan open ended merupakan pendekatan pembelajaran yang menggunakan masalah terbuka yang dapat dijawab dengan banyak cara/metode penyelesaian atau jawaban benar yang beragam. Dengan keberagaman cara penyelesaian dan jawaban tersebut, maka memberikan keleluasaan kepada siswa dalam menyelesaikan masalah. Siswa dapat menggali pengetahuan ataupun sumber-sumber yang dibutuhkan untuk menarik suatu kesimpulan, membuat rencana dan memilih cara atau metode dalam menyelesaikan masalah, serta menerapkan kemampuan matematika mereka sehingga diharapkan siswa dapat memperoleh pengetahuan melalui pengalaman menemukan sesuatu yang baru dalam suatu proses penyelesaian masalah.

Pembelajaran dengan pendekatan Open-Ended diawali dengan memberikan masalah terbuka kepada siswa, dan kegiatannya harus mengarah dan membawa siswa dalam menjawab masalah dengan banyak cara serta mungkin juga dengan banyak jawaban (yang benar), sehingga merangsang kemampuan intelektual dan pengalaman siswa dalam proses menemukan sesuatu yang baru. Pendekatan Open-Ended juga memberikan kesempatan kepada siswa untuk meginvestigasi berbagai strategi dan cara yang diyakininya sesuai dengan kemampuan mengelaborasi permasalahan. Pendekatan Open-Ended bertujuan agar siswa memiliki kemampuan berpikir matematika dan dapat berkembang secara maksimal dan kegiatan-kegiatan kreatif dari setiap siswa terkomunikasi untuk menjawab permasalahan melalui berbagai strategi. Siswa yang dihadapkan dengan Open-Ended problem, tujuan utamanya bukan untuk mendapatkan 
jawaban tetapi lebih menekankan pada cara bagaimana sampai pada suatu jawaban.

Masalah yang diambil dengan menggunakan pendekatan Open-Ended dapat diperoleh dari masalah yang konstektual (real world) dan masalah dalam matematika $a_{21}$. Masalah konstekstual diambil dari masalah-masalah keseharian atau masalah-masalah yang dapat dipahami oleh pikiran siswa. Dengan masalah itu peserta didik akan dibawa kepada konsep matematika melalui reinvetion atau melalui discovery. Open-Ended problem merupakan masalah dasar keterbukaanya (openness) dapat diklasifikasikan kedalam tiga tipe, yakni: (1) process is open: tipe soal yang mempunyai banyak cara penyelesaian yang benar, (2) end product are open: tipe soal mempunyai jawaban benar yang banyak (multiple), (3) ways to develop are open, setelah selesai menyelesaikan masalahnya, masalah baru dapat dikembangkan dengan mengubah kondisi dari masalah sebelumnya (Becker \& Shimada 22 ; Cifarelli \& $\mathrm{Cai}_{23}$; Subanji 24 . Pemberian tugas untuk open ended problem dapat mengevaluasi keragaman pengetahuan dan mendorong berfikir kreatif

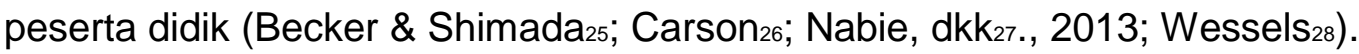

Peneliti lainnya terhadap kajian Open-Ended problem (Georgios Kosyvas) juga menggambarkan argumen-argumen karakteristik yang mewakili berbagai bentuk penalaran tertentu yang muncul selama proses pembelajaran. Lingkungan yang kondusif untuk kreativitas, mendorong peserta didik berkolaborasi, bereksplorasi dan berbagi ide, dan juga peserta didik dapat terlibat dalam mengembangkan berbagai strategi matematika, mengajukan pertanyaan baru,

${ }^{21}$ Becker, Jerry P. dan Shigeru Shimada. The Open Ended Approach: a New Proposal for Teaching Mathematics (Virginia: NCTM, 1997), hlm. 1

${ }^{22}$ lbid.

${ }^{23}$ Cifarelli, Victor V dan Jinfa Cai. The Evolution of Mathematical Explorations in OpenEnded Problem-Solving Situations. Journal of Mathematical Behavior, 24: 302-324. doi:

10.1016/j.jmathb.2005.09.007

${ }^{24}$ Subanji. 2013. Pembelajaran Matematika Kreatif dan Inovatif. Malang: Universitas Negeri Malang.

${ }^{25}$ Becker, Jerry P. dan Shigeru Shimada, Loc.Cit.

${ }^{26}$ Carson, J. A Problem with Problem Solving: Teaching Thinking without Teaching Knowledge. The Mathematics Educator, 17 (2): 7-14, 2007

${ }^{27}$ Nabie, M.J., Akayuure, P., \& Sofo, S. Integrating Problem Solving and Investigations in Mathematics. International Journal of Humanities and Social Science, 3 (15): 46-56, 2013.

${ }^{28}$ Wessels, $\mathrm{H}$. Levels of Mathematical Creativity in Model-Eliciting Activities. Journal of Mathematical Modelling and Application, 1 (9): 22-40, 2014 
menciptakan bukti informal untuk memecahkan masalah. Pemecahan masalah adalah cara yang ampuh untuk belajar matematika 29.

Rimbatmojo menganalisis tentang kesulitan metakognisi peserta didik dengan kecerdasan visual-spasial dalam menyelesaikan masalah terbuka (OpenEnded) dalam pembelajaran matematika. Dengan menggunakan penelitian kualitatif dengan menggunakan tes kecerdasan visual spasial dan rekaman wawancara diperoleh hasil penelitian (1) peserta didik dengan kecerdasan visualspasial tinggi tidak mengalami kesulitan pada setiap aspek metakognisi, (2) peserta didik dengan kecerdasan visual-spasial menengah mengalami kesulitan pada aspek pengetahuan pada strategi dan tugas kognitif, (3) peserta didik dengan kecerdasan visual-spasial rendah, mengalami kesulitan pada tiga aspek metakognisi, yaitu pengetahuan tentang strategi, tugas-tugas kognitif dan pengetahuan diri. Untuk penelitian lanjutan, sangat untuk membahas bahwa kesulitan metakognitif yang terjadi karena beberapa faktor, salah satunya pada

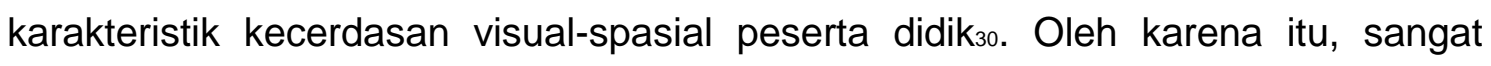
penting bagi pendidik matematika untuk mempertimbangkan dan lebih memperhatikan kecerdasan visual-spasial peserta didik dan kesulitan metakognisi dalam merancang pembelajaran matematika yang lebih baik.

Dengan demikian jika seorang guru menerapkan pendekatan open ended dalam pembelajaran matematika maka guru perlu memikirkan prediksi respon siswa atas situasi masalah terbuka sehingga akan memperlancar jalannya proses pembelajaran dan terpeliharanya hubungan yang baik dalam situasi didaktis dan pedagogis.

\section{Penalaran Matematik Melalui Pendekatan Open-Ended}

Untuk mengetahui penalaran matematika, guru dapat memberikan suatu masalah kepada siswa untuk diselesaikan. Salah satu masalah yang dapat diberikan adalah jenis masalah terbuka (open ended). Masalah terbuka (open ended) dapat memberi kesempatan kepada siswa untuk menggunakan berbagai macam cara atau solusi dalam memecahkan masalah. Oleh karena itu, masalah

29 Georgios Kosyvas, Levels of arithmetic reasoning in solving an open-ended problem (International Journal of Mathematical Education in Science and Technology, Vo. 47, 2016 Issue 3) : 356-372

${ }^{30} \mathrm{~S}$ Rimbatmojo, T A Kusmayadi and R Riyadi, Metacognition Difficulty of Students with Visual-Spatial Intelligence during Solving Open-Ended Problem, (International Conference on

Mathematics and Science Education (ICMScE), OP Conf. Series: Journal of Physics: Conf. Series 895 (2017) 012034) 
open ended dapat memberikan kesempatan lebih kepada siswa untuk mengembangkan penalarannya (Bocker dan Shimada dalam Sudia). ${ }_{31}$ Sehingga dengan pemberian masalah open ended guru diharapkan dapat menggali penalaran siswa.

Joko Sulianto, hasil penelitiannya menunjukkan bahwa dengan pendekatan open ended ini memberikan kontribusi kemampuan memecahkan masalah yang lebih baik sebab dalam anggota kelompok tersebut terjadi diskusi sehingga terjadi interaksi tatap muka dan keterampilan dalam menjalin hubungan interpersonal. Pada model ini siswa akan berkembang kemampuan kognitif maupun kemampuan verbalnya. Kemampuan kognitif dapat berkembang karena ada tuntutan untuk menyelesaikan masalah, dan dengan memberikan informasi kepada sesama anggota dan kelompok lain pada saat diskusi dalam satu kelas sehingga akan mengembangkan kemampuan berbicara (verbal). Pembelajaran dengan pendekatan open ended melatih siswa bertanggung jawab untuk menyelesaikan tugasnya masing-masing dan dapat mengembangkan keterampilan memecahkan masalah sehingga siswa dapat mengembangkan penalarannya dengan baik ${ }^{32}$.

Megawati dalam hasil penelitiannya menemukan bahwa kemampuan matematika siswa berpengaruh pada kemampuan penalaran matematik. Siswa yang memiliki kemampuan matematika tinggi cenderung memiliki kemampuan bernalar yang sangat baik. Siswa yang memiliki kemampuan matematika sedang cenderung memiliki kemampuan bernalar yang cukup baik, sedangkan siswa yang memiliki kemampuan matematika rendah cenderung memiliki kemampuan bernalar yang kurang baik. 33

Asri Nasrotul Mualifah dan Agung Lukito, hasil penelitiannya menunjukkan bahwa dalam memahami masalah dengan pendekatan open-ended, siswa dengan kemampuan matematika tinggi, seluruh indikator penalaran terpenuhi pada tahap memahami masalah, melaksanakan rencana, dan memeriksa kembali solusi, sedangkan pada tahap menyusun rencana terdapat satu indikator penalaran yang belum terpenuhi. Untuk siswa berkemampuan matematika sedang, seluruh indikator penalaran terpenuhi pada tahap memahami masalah dan melaksanakan

\footnotetext{
${ }^{31}$ Sudia, M. Profil Metakognisi Siswa SMP yang Bergaya Kognitif Impulsive-Reflektif dalam Memecahkan Masalah Terbuka Materi Geometri Ditinjau dari Perbedaan Jenis Kelamin. Tesis Tidak

Dipublikasikan. (Surabaya: Pasca Sarjana Unesa,

2013). ${ }^{32}$ Joko Sulianto, Loc. Cit.,

${ }^{33}$ Megawati, D. Profil Penalaran Siswa SMA Al Hikmah Surabaya dalam Membuktikan Identitas Trigonometri Ditinjau dari Kemampuan Matematika. Tesis Tidak Dipublikasikan.

Surabaya: Pasca Sarjana Unesa, 2013).
} 
rencana, sedangkan pada tahap menyusun rencana dan memeriksa kembali solusi terdapat satu indikator penalaran yang belum terpenuhi. Untuk siswa berkemampuan matematika rendah, pada tahap memahami masalah, menyusun rencana, melaksanakan rencana, dan memeriksa kembali solusi, terdapat indikator penalaran yang belum terpenuhi. 34

Berdasarkan hasil dan temuan penelitian yang telah dilakukan oleh Ratna Sariningsih dan Indri Herdiman, bahwa penerapan pembelajaran dengan pendekatan open-ended memiliki dampak atau berkontribusi terhadap terbentuknya kemampuan penalaran, kemampuan berpikir kreatif matematis, dan kemampuan berpikir reflektif matematis ${ }^{35}$. Dari hasil penelitian yang telah dilakukan, pembelajaran menggunakan pendekatan open-ended melalui kelompok kecil berjalan sesuai dengan yang diharapkan dan menunjukan peran yang berarti dalam meningkatkan ke-mampuan kemampuan penalaran statistik, kemampuan berpikir kreatif matematis, dan kemampuan berpikir reflektif matematis.

Devi Emilya, Darmawijoyo, dan Ratu Ilma Indra Putri, hasil penelitiannya menunjukkan bahwa dengan mengembangkan soal-soal melalui pendekatan Open-Ended memiliki efek potensial terhadap penalaran matematika siswa yaitu a). memiliki keberagaman solusi dari siswa; b). Tingkat penalaran siswa pada tes terkategori baik dan sangat baik. ${ }^{36}$

Mason mengatakan bahwa yang mendasari penalaran matematik seseorang adalah spesialisasi, generalisasi, dugaan, dan pembenaran. Seorang siswa dalam melakukan penalaran matematik harus memiliki kemampuan atau pengetahuan dalam memecahkan masalah matematika dan menjelaskan atau memberikan alasan penyelesaian dilakukan berdasarkan pola berpikir logis dan analitis. ${ }^{37}$ Berdasarkan hasil dari beberapa penelitian tersebut, maka penalaran matematik melalui pendekatan Open-Ended adalah proses berpikir logis dalam mencapai

${ }^{34}$ Asril Nasrotul Mualifah dan Agung Lukito, Profil Penalaran Siswa dalam Pemecahan Masalah Open-Ended ditinjau dari Kemampuan Matematika (Mathedunesa Jurnal IImiah Pendidikan Matematika Vol 3 No 3, 2014)

${ }^{35}$ Ratna Sariningsih dan Indri Herdiman, Mengembangkan Kemampuan Penalaran Statistik dan Berpikir Kreatif Matematis Mahasiswa Melalui Pendekatan Open-ended (Jurnal Riset

Pendidikan Matematika 4 (2), 2017), hlm. 239-246

${ }^{36}$ Devi Emilya, Darmawijoyo, dan Ratu IIma Indra Putri, Pengembangan Soal-soal OpenEnded Materi Lingkaran untuk Meningkatkan Penalaran Matematika Siswa Kelas VIII SMP Negeri 10 Palembang (Jurnal Pendidikan Matematika Vol. 4, No. 2, 2010)

${ }^{37}$ Mason, J et.al. Thinking Mathematically Second Edition. (England: Pearson Education Limited, 2010), hlm. 135 
kesimpulan yang mengandung kegiatan dengan spesialisasi (mengumpulkan fakta, seperti apa yang diketahui dan ditanya), generalisasi (membuat pola matematik secara umum), dugaan (memberikan dugaan, memeriksa dugaan, dan menguji dugaan, dan membenarkan (memberikan argument dan membuat kesimpulan).

\section{PENUTUP}

Berdasarkan hasil penelitian dari beberapa peneliti terdahulu, dapat disimpulkan bahwa melalui pendekatan Open-Ended menjadikan pembelajaran matematika lebih bermakna dan berkontribusi pada terbentuknya kemampuan penalaran matematik. Siswa dapat menggali pengetahuan ataupun sumbersumber yang dibutuhkan serta menerapkan kemampuan matematika mereka sehingga diharapkan siswa dapat memperoleh pengetahuan melalui pengalaman menemukan sesuatu yang baru dalam suatu proses penyelesaian masalah.

\section{DAFTAR PUSTAKA}

Asril Nasrotul Mualifah dan Agung Lukito, Profil Penalaran Siswa dalam Pemecahan Masalah Open-Ended ditinjau dari Kemampuan Matematika Mathedunesa Jurnal IImiah Pendidikan Matematika Vol 3 No 3, 2014.

Becker, Jerry P. dan Shigeru Shimada. The Open Ended Approach: a New Proposal for Teaching Mathematics, Virginia: NCTM, 1997.

Carson, J. A Problem with Problem Solving: Teaching Thinking without Teaching Knowledge. The Mathematics Educator, 17 (2): 7-14, 2007

Cifarelli, Victor V dan Jinfa Cai. The Evolution of Mathematical Explorations in Open-Ended Problem-Solving Situations. Journal of Mathematical Behavior, 24: 302-324. doi: 10.1016/j.jmathb.2005.09.007

De Lange, J. Mathematical literacy for living from OECD-PISA perspective. Tsukuba Journal of Educational Study in Mathematics, 2006.

Eka Kasah Gordah, Upaya Guru Meningkatkan Kemampuan Koneksi dan Pemecahan Masalah Matematis Peserta Didik melalui Pendekatan Open Ended, Jurnal Pendidikan dan Kebudayaan Vol 18, No 3, 2012.

Emilya, Devi, Darmawijoyo, dan Ratu IIma Indra Putri, Pengembangan Soal-soal Open-Ended Materi Lingkaran untuk Meningkatkan Penalaran Matematika 
Siswa Kelas VIII SMP Negeri 10 Palembang, Jurnal Pendidikan Matematika Vol. 4, No. 2, 2010.

Georgios Kosyvas, Levels of arithmetic reasoning in solving an open-ended problem, International Journal of Mathematical Education in Science and Technology, Vo. 47, 2016 - Issue 3.

Hasratuddin, Mengapa Harus Belajar Matematika? Medan: Perdana Publishing, 2015.

Herdiman, I. Penerapan pendekatan open-ended untuk meningkatkan pemahaman dan penalaran matematik serta kemandirian belajar siswa SMP. Tesis STKIP Siliwangi, tidak diterbitkan, 2015.

Hudoyo, Pengembangan Kurikulum Matematika dan Pelaksanaannya di Depan Kelas. Surabaya: Usaha Nasional, 1988.

Mason, J et.al. Thinking Mathematically Second Edition. England: Pearson Education Limited, 2010

Megawati, D. Profil Penalaran Siswa SMA Al Hikmah Surabaya dalam Membuktikan Identitas Trigonometri Ditinjau dari Kemampuan Matematika. Tesis Tidak Dipublikasikan. Surabaya: Pasca Sarjana Unesa, 2013.

Muhsetyo, Gatot. Pembelajaran Matematika SD, Tangerang Selatan: Universitas Terbuka, 2015.

Mullis, et al., TIMSS Assessment Frameworks and specifications 2003. 2nd Edition. International Study Center, Lynch School of Education, Boston College, 2003.

Nabie, M.J., Akayuure, P., \& Sofo, S. Integrating Problem Solving and Investigations in Mathematics. International Journal of Humanities and Social Science, 3 (15): 46-56, 2013.

NCTM. Principles and Standards for School Mathematics. Drive, Reston, VA: The NCTM, 2000.

Nizar, Achmad. Kontribusi Matematika dalam Membangun Daya Nalar dan Komunikasi Siswa, Jurnal Pendidikan Inovatif/Vol. 2, No.2, 2007.

Rimbatmojo, S, T. A. Kusmayadi and R Riyadi, Metacognition Difficulty of Students with Visual-Spatial Intelligence during Solving Open-Ended Problem, International Conference on Mathematics and Science Education (ICMScE), OP Conf. Series: Journal of Physics: Conf. Series 895 2017, 012034. 
Ruseffendi, E.T. Pengantar kepada Membantu Guru Mengembangkan Kompetensinya dalam Pengajaran matematika untuk Meningkatkan CBSA. Bandung: Tarsito, 1991.

Sariningsih, Ratna dan Indri Herdiman, Mengembangkan Kemampuan Penalaran Statistik dan Berpikir Kreatif Matematis Mahasiswa Melalui Pendekatan Open-ended, Jurnal Riset Pendidikan Matematika 4 (2), 2017.

Suherman, E dan Winataputra, U.S. Strategi Belajar Mengajar Matematika, Jakarta: Universitas Terbuka, 1993.

Sumarmo, U. "Kemampuan Pemahaman Dan Penalaran Matematik Siswa SMA Dikaitkan Dengan Kemampuan Penalaran Logik Siswa Dan Beberapa Unsur Proses Belajar Mengajar." Dissertation In Post Graduate Study, Institut Keguruan Dan IImu Pendidikan, Bandung. Un published, 1987.

Nasional Pendidikan Matematika STKIP Siliwangi Bandung Vol. 1, 2011.

Kurikulum Berbasis Kompetensi. Makalah Disajikan pada Pelatihan Guru, 2002.

Soeyono, Yandri. Pengembangan Bahan Ajar Matematika dengan Pendekatan Open-Ended untuk Meningkatkan Kemampuan Berpikir Kritis dan Kreatif Siswa SMA, PYTHAGORAS: Jurnal Pendidikan Matematika Volume 9Nomor 2, Desember 2014.

Subanji. 2013. Pembelajaran Matematika Kreatif dan Inovatif. Malang: Universitas Negeri Malang.

Sudia, M. Profil Metakognisi Siswa SMP yang Bergaya Kognitif ImpulsiveReflektif dalam Memecahkan Masalah Terbuka Materi Geometri Ditinjau dari Perbedaan Jenis Kelamin. Tesis Tidak Dipublikasikan. Surabaya: Pasca Sarjana Unesa, 2013.

Sulianto, Joko. Keefektifan Model Pembelajaran Kontekstual dengan pendekatan open ended dalam aspek penalaran dan pemecahan masalah pada materi segitiga di kelas VII. Malih Peddas: Majalah IImiah Penddikan Dasar Vol 1, No 1, 2011. 
Wessels, $\mathrm{H}$. Levels of Mathematical Creativity in Model-Eliciting Activities. Journal of Mathematical Modelling and Application, 1 (9): 22-40, 2014.

Widjaya, W. Design Realistic Mathematics Education Lesson. Makalah Seminar Nasional Pendidikan, Program Pascasarjana Universitas Sriwijaya, Palembang, 2010. 